Article

\title{
Horse Oil Mitigates Oxidative Damage to Human HaCaT Keratinocytes Caused by Ultraviolet B Irradiation
}

\author{
Mei Jing Piao ${ }^{1}$, Kyoung Ah Kang ${ }^{1}$, Ao Xuan Zhen ${ }^{1}$, Hee Kyoung Kang ${ }^{1}$, Young Sang Koh ${ }^{1}$, \\ Bong Seok Kim ${ }^{2}$ and Jin Won Hyun ${ }^{1, *}$ \\ 1 School of Medicine, Jeju National University, Jeju 63243, Korea; meijing0219@hotmail.com (M.J.P.); \\ legna48@hanmail.net (K.A.K.); zhenaoxuan705@gmail.com (A.X.Z.); pharmkhk@jejunu.ac.kr (H.K.K.); \\ yskoh7@jejunu.ac.kr (Y.S.K.) \\ 2 Bio Convergence Center, Jeju Technopark, Jeju 63243, Korea; kbs6953@jejutp.or.kr \\ * Correspondence: jinwonh@jejunu.ac.kr; Tel.: +82-64-754-3838
}

Received: 14 February 2019; Accepted: 22 March 2019; Published: 25 March 2019

\begin{abstract}
Horse oil products have been used in skin care for a long time in traditional medicine, but the biological effects of horse oil on the skin remain unclear. This study was conducted to evaluate the protective effect of horse oil on ultraviolet B (UVB)-induced oxidative stress in human HaCaT keratinocytes. Horse oil significantly reduced UVB-induced intracellular reactive oxygen species and intracellular oxidative damage to lipids, proteins, and DNA. Horse oil absorbed light in the UVB range of the electromagnetic spectrum and suppressed the generation of cyclobutane pyrimidine dimers, a photoproduct of UVB irradiation. Western blotting showed that horse oil increased the UVB-induced Bcl-2/Bax ratio, inhibited mitochondria-mediated apoptosis and matrix metalloproteinase expression, and altered mitogen-activated protein kinase signaling-related proteins. These effects were conferred by increased phosphorylation of extracellular signal-regulated kinase $1 / 2$ and decreased phosphorylation of p38 and c-Jun N-terminal kinase 1/2. Additionally, horse oil reduced UVB-induced binding of activator protein 1 to the matrix metalloproteinase- 1 promoter site. These results indicate that horse oil protects human $\mathrm{HaCaT}$ keratinocytes from UVB-induced oxidative stress by absorbing UVB radiation and removing reactive oxygen species, thereby protecting cells from structural damage and preventing cell death and aging. In conclusion, horse oil is a potential skin protectant against skin damage involving oxidative stress.
\end{abstract}

Keywords: horse oil; ultraviolet B radiation; oxidative stress; apoptosis

\section{Introduction}

In many Asian countries including Korea, horse oil has long been used as a folk medicine. The efficacy of horse oil in hair care, beauty, and scar healing is described in classical medicine books such as "Mingyi Bielu", "Compendium of Materia Medica", and "Huang di's Canon of Medicine"; however, few studies have examined these effects using modern techniques. Analysis of the ester fraction of horse oil revealed that C18 unsaturated acids, comprising 57\% of total fatty acids, include oleic acid (60\%), hepta-decadiene-carboxylic acid (linoleic acid isomer; 10\%), and hepta-decatriene-carboxylic (linolenic) acid (30\%) [1]. Recent studies have shown that oleic acid has anti-oxidative [2-4] and anti-inflammatory effects [5] as well as inhibits matrix metalloproteinases (MMPs) [6].

Both ultraviolet (UV) A and UVB reach the surface of the earth and penetrate the skin, inducing the production of a large amount of reactive oxygen species (ROS), thereby disrupting the redox balance in the organism to induce oxidative stress $[7,8]$. Many studies have demonstrated that UVB 
damages the skin by inducing oxidative stress, leading to a range of skin conditions including erythema [9], burns [10], inflammation [11], photo-aging [12], photo-carcinogenesis [13], and ultimately skin cancer [14]. Moreover, UVB is directly absorbed by DNA and generates pyrimidine adducts, such as cyclobutane pyrimidine dimer (CPD) and pyrimidine-pyrimidone (6-4) photoproducts [15], which are easily mutable substances [16]. MMPs are a family of matrix-degrading enzymes with important roles in various disruptive events, such as inflammation, cancer invasion and metastasis, and skin senescence $[17,18]$. Various studies have demonstrated that UVB-induced expression of MMPs (MMP-1, MMP-2, MMP-9) leads to collagen degradation [19-21]. UVB irradiation can mediate apoptosis via oxidative stress-dependent phosphorylation of upstream mitogen-activated protein kinases (MAPKs) in human HaCaT keratinocytes. Moreover, UV-generated ROS have been shown to stimulate the MAPK signaling pathway and transcription factor activator protein 1 (AP-1), leading to upregulation of MMP expression [22].

Here, we evaluated the protective effect of horse oil against UVB-induced photo-oxidative damage and photo-aging in human HaCaT keratinocytes.

\section{Results}

\subsection{Analysis of Horse Oil Composition}

According to the composition analysis report of the Korea Food Research Institute, the occupancy ratios of saturated fat in horse oil fat are 30.3\% for HO-I and $42.1 \%$ for HO-II. The main ingredient is palmitic acid, accounting for $23.8 \%$ and $29.4 \%$ in HO-I and HO-II, respectively. The ratios of unsaturated fat in HO-I and HO-II are $69.3 \%$ and $57.1 \%$, respectively, with oleic acid and linoleic acid as the major unsaturated fatty acids. The ratios of oleic acid and linoleic acid are $37.7 \%$ and $19.7 \%$ in HO-I and $32.5 \%$ and $15.0 \%$ in HO-II, respectively (Table 1 ).

Table 1. Fatty acid contents of horse oils.

\begin{tabular}{ccc}
\hline Fatty Acid & HO-I (\%) & HO-II (\%) \\
\hline C10:0 Capric acid & & 0.1 \\
C12:0 Lauric acid & 0.2 & 2.1 \\
C14:0 Myristic acid & 3.5 & 5.7 \\
C16:0 Palmitic acid & 23.8 & 29.4 \\
C18:0 Stearic acid & 2.8 & 4.8 \\
\hline Saturated fatty acid & 30.3 & 42.1 \\
\hline C14:1 Myristoleic acid & 0.4 & 0.3 \\
C16:1 Palmitoleic acid & 7.9 & 5.2 \\
C18:1 Oleic acid & 37.7 & 32.5 \\
C18:2 Linoleic acid & 19.7 & 15.0 \\
C18:3 Linolenic acid & 2.5 & 3.1 \\
C20:1 Gadoleic acid & 0.7 & 0.7 \\
C20:2 Eicosadienoic acid & 0.4 & 0.3 \\
\hline Unsaturated fatty acid & 69.3 & 57.1 \\
\hline Unknown & 0.4 & 0.8 \\
\hline Total & 100 & 100 \\
\hline
\end{tabular}

\subsection{Effect of Horse Oil on UVB-Induced ROS Generation}

Horse oil showed no toxicity towards human $\mathrm{HaCaT}$ keratinocytes at a concentration equal to or lower than $0.625 \%$; however, HO-I was cytotoxic at concentrations above $1.25 \%$ and HO-II was cytotoxic at concentrations above $2.5 \%$ (Figure 1a). In cell-free systems, horse oil scavenges DPPH free radicals in a concentration-dependent manner. HO-I and HO-II showed the best free radical scavenging effects of $71 \%$ and $70 \%$, respectively, which were equivalent to $70 \%$ of the positive control $\mathrm{N}$-acetylcysteine (NAC), at the highest concentration of $2.5 \%$ (Figure $1 \mathrm{~b}$ ). In the cell system, horse oil 
also effectively scavenged $\mathrm{H}_{2} \mathrm{O}_{2}$ or UVB-induced ROS. HO-I and HO-II at $0.312 \%$ exhibited the best scavenging effect in $\mathrm{H}_{2} \mathrm{O}_{2}$ test groups, scavenging $49 \%$ and $33 \%$ of ROS, respectively. For UVB test groups, the strongest effect was observed at a concentration of $1.25 \%$, reducing ROS by $24 \%$ and $31 \%$, respectively. These effects were close to the $50 \%$ or $52 \%$ scavenging effects of NAC (Figure 1c,d). Considering the cytotoxicity and scavenging effects, we selected $0.312 \%$ as the optimal concentration of horse oil for further experiments. Confocal microscopy revealed that the red fluorescence intensity of dichlorodihydrofluorescein produced by the reaction of $\mathrm{H}_{2}$ DCFDA and ROS was significantly reduced in $0.312 \%$ horse oil-pretreated cells compared to UVB-irradiated cells (Figure 1e). Flow-cytometric analysis of UVB-irradiated ROS levels revealed that the fluorescence intensity in the UVB-exposed group was 196, whereas those in the cells pretreated with HO-I and HO-II were 112 and 109, respectively (Figure 1f).

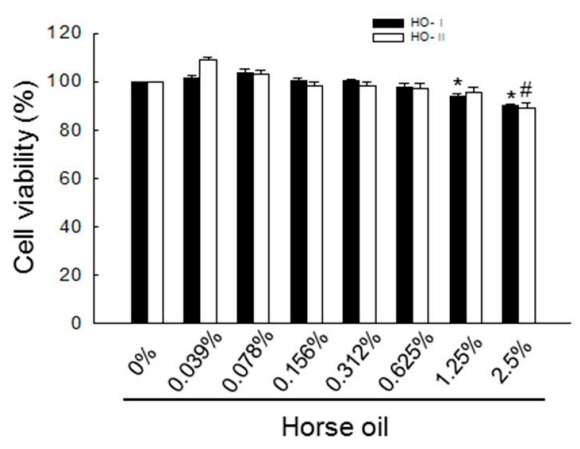

(a)

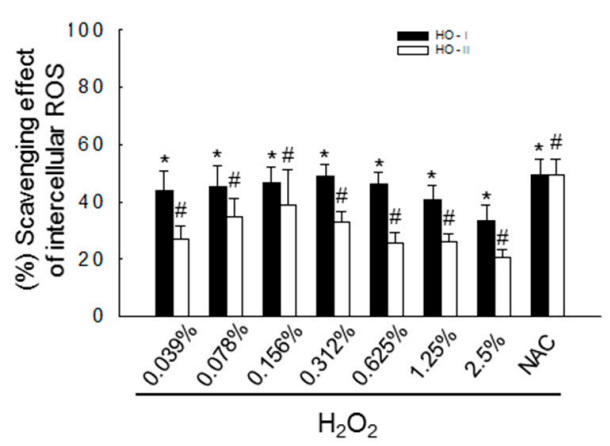

(c)

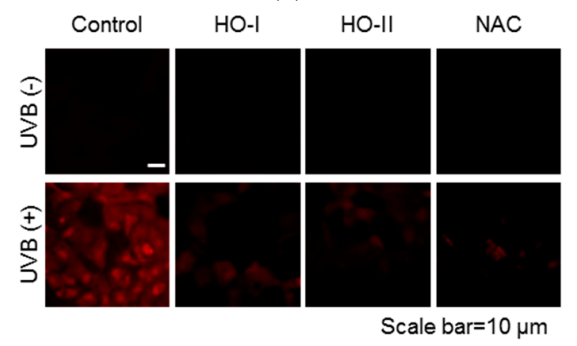

(e)

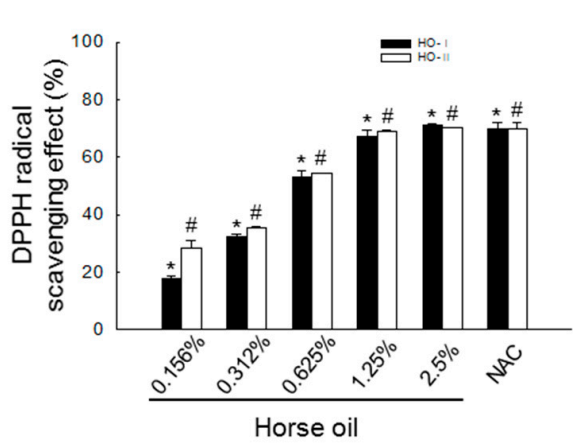

(b)

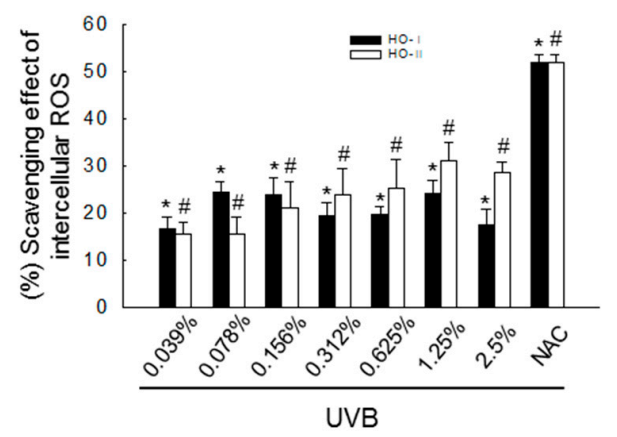

(d)

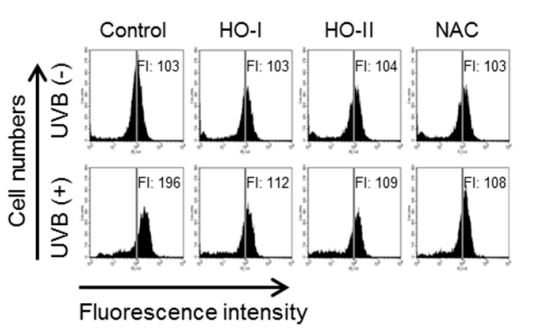

(f)

Figure 1. Horse oil can scavenge stress-induced ROS. (a) Horse oil (HO-I or HO-II) was added at the indicated final concentrations. After $24 \mathrm{~h}$, cell viability was measured by MTT assay. (b) DPPH radical levels were measured spectrophotometrically at $520 \mathrm{~nm}$. *, \#p<0.05 vs. non-treated control cells. Intracellular ROS levels generated by (c) $\mathrm{H}_{2} \mathrm{O}_{2}$ or (d) UVB radiation were detected by spectrofluorometry after $\mathrm{H}_{2}$ DCFDA staining. NAC served as a positive control. * $p<0.05$ vs. $\mathrm{H}_{2} \mathrm{O}_{2}$ alone, and $\# p<0.05$ vs. UVB alone. Cells were treated with $0.312 \%$ horse oil for $1 \mathrm{~h}$, and then with UVB radiation at $30 \mathrm{~mJ} / \mathrm{cm}^{2}$. Next, the cells were incubated for $24 \mathrm{~h}$, and intracellular ROS were detected by (e) confocal microscopy (Scale bar $=10 \mu \mathrm{m}$ ) and (f) flow cytometry after $\mathrm{H}_{2}$ DCFDA staining. 


\subsection{Effect of Horse Oil on UVB-Induced Macromolecular Damage}

We next evaluated UVB-mediated oxidative damage of cellular structures and the protective properties of horse oil by assessing the extent of lipid peroxidation, protein carbonyl formation, and DNA strand breaks. Lipid peroxidation was evaluated by detecting total 8-isoprostane in conditioned cell culture media. Cells exposed to UVB showed increased 8-isoprostane levels ( $229 \mathrm{pg} / \mathrm{mL}$ ) compared to the control group $(191 \mathrm{pg} / \mathrm{mL})$. However, pretreatment with horse oil (193 and $210 \mathrm{pg} / \mathrm{mL})$ attenuated the UVB-induced elevation in 8-isoprostane levels (Figure 2a). The fluorescence intensity of DPPP oxide was stronger in UVB-irradiated cells than in control cells. However, pretreatment of cells with horse oil considerably reduced lipid peroxidation in UVB-irradiated cells, as did pretreatment with NAC (Figure $2 b$ ). Protein carbonylation is a form of oxidative protein damage promoted by UVB-generated ROS. The protein carbonyl content of cells exposed to UVB $(8.7 \mathrm{nmol} / \mathrm{mg})$ was noticeably higher than that in control cells; however, HO-I and HO-II pretreatment significantly reduced the protein carbonyl content to 7.6 and $7.4 \mathrm{nmol} / \mathrm{mg}$, respectively. The effects of the horse oils were similar to that of NAC, which reduced the protein carbonyl content to $7.1 \mathrm{nmol} / \mathrm{mg}$ (Figure 2c). Finally, an alkaline comet assay was performed to visualize DNA damage in cells resulting from UVB irradiation. Exposure of keratinocytes to UVB irradiation increased the number of DNA strand breaks, which increased the fluorescence intensity in the tails of comet-like structures formed during the comet assay. Obvious comet tail formation was observed in UVB-treated cells compared to in control cells, but horse oil and NAC pretreatment both attenuated this phenomenon. Quantification in image analysis revealed that the portion of total cellular DNA in tails in cells exposed to UVB was $37 \%$, while those in the HO-I-, HO-II-, and NAC-pretreated UVB-irradiated cells were $16 \%, 18 \%$, and $15 \%$, respectively (Figure 2d). The level of 8-oxoG, a hallmark of oxidative stress-induced DNA base damage, was detected in an avidin-TRITC assay and verified by confocal microscopy. The fluorescence intensity in UVB-irradiated cells treated with horse oil was significantly weaker than that in cells irradiated with UVB alone (Figure 2e). Because UV light induced the production of CPDs, which represent $70-80 \%$ of total UV-induced photoproducts, the effect of horse oil on UVB-induced CPD production was detected. The CPD level in UVB-exposed cells was 2.63-fold higher than that in control cells, as indicated by enzyme-linked immunosorbent assay (ELISA); however, horse oil pretreatment significantly inhibited the UVB-induced CPD level by up to 2.27- and 2.23-fold, respectively (Figure 2f). Immunocytochemical analysis confirmed this finding (Figure $2 \mathrm{~g}$ ).

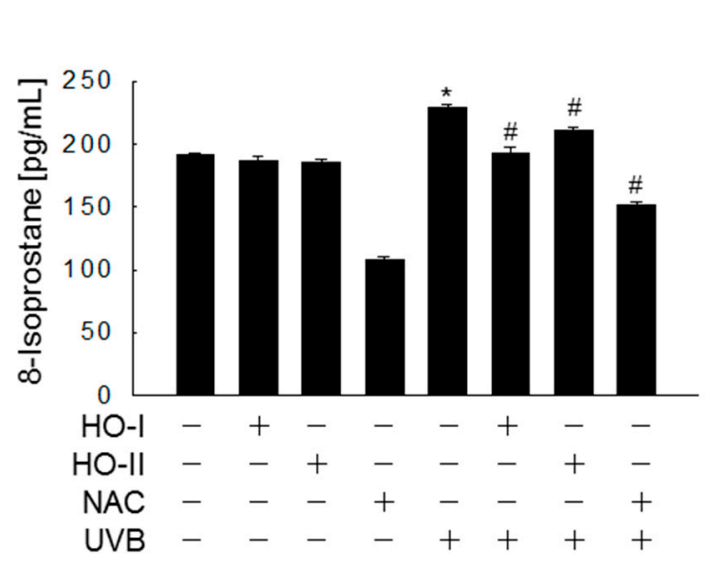

(a)

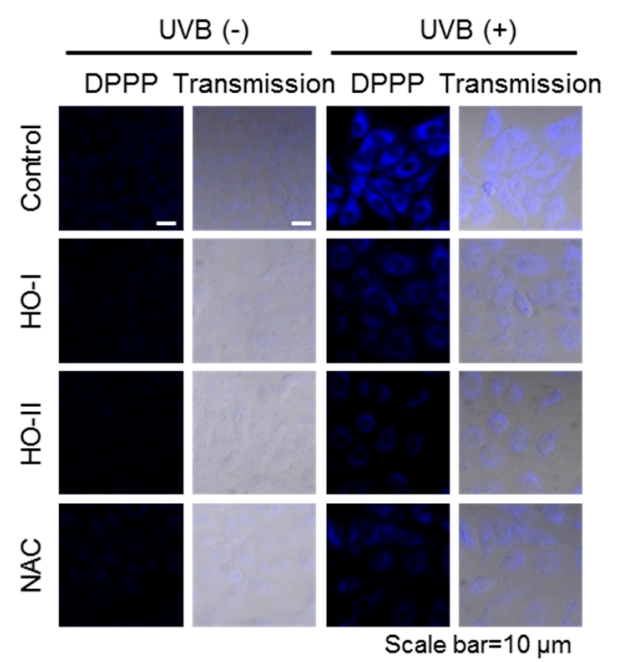

(b)

Figure 2. Cont. 


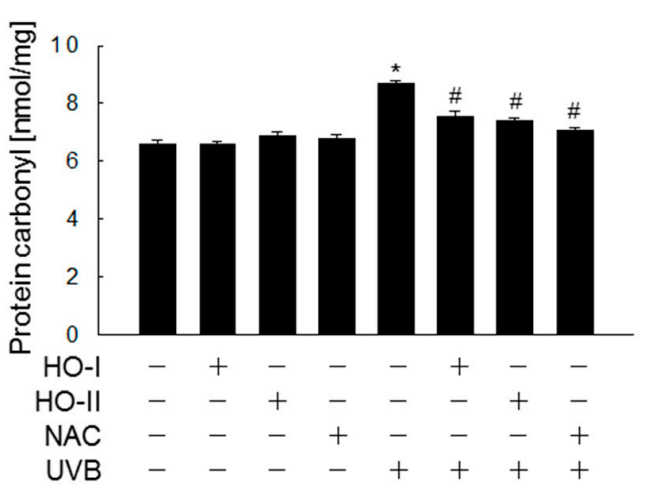

(c)

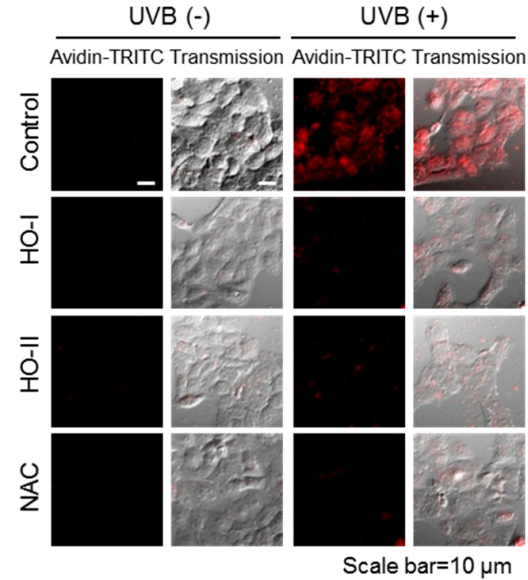

(e)

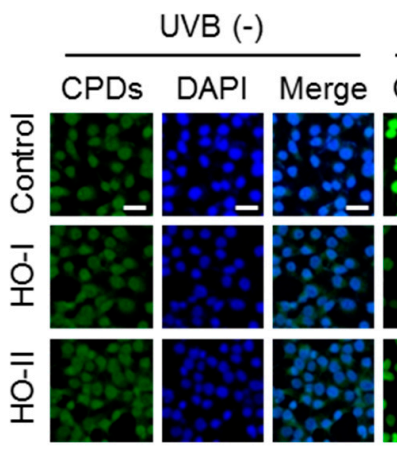

(g)

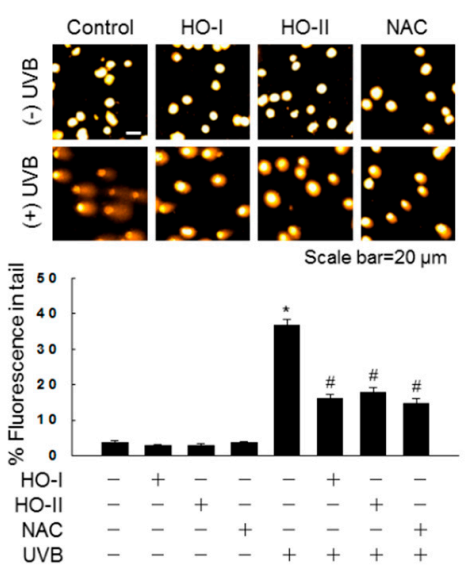

(d)

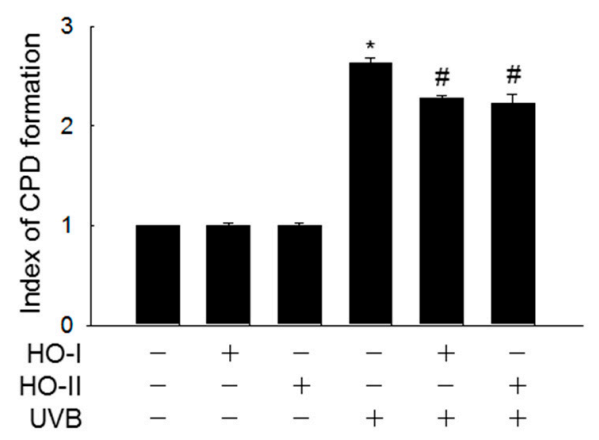

(f)
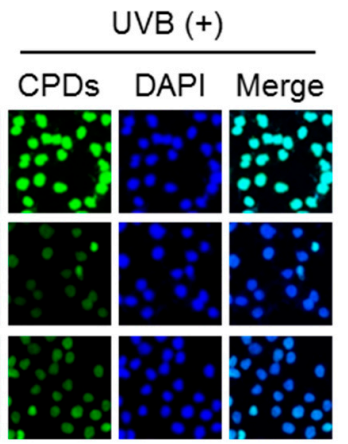

Scale bar $=10 \mu \mathrm{m}$

Figure 2. Horse oil mitigates UVB-induced oxidative damage to cellular macromolecules. Cells were treated with horse oil or NAC for $1 \mathrm{~h}$ and then exposed to UVB radiation. After incubation, lipid peroxidation was assayed by measuring (a) the levels of 8-isoprostane secreted into the culture medium or (b) DPPP-stained cells were detected by confocal microscopy and quantified (Scale bar $=10 \mu \mathrm{m}$ ). (c) Protein oxidation was assayed by measuring protein carbonylation. (d) DNA damage was assessed by the comet assay. Representative images and the percentage of total cellular DNA in comet tails are shown (Scale bar $=10 \mu \mathrm{m}$ ). ${ }^{*} p<0.05$ vs. control, and $\# p<0.05$ vs. UVB-irradiated cells. (e) 8-OxoG detected by the binding of avidin-TRITC was visualized by confocal microscopy (Scale bar=10 $\mu \mathrm{m}$ ). DNA was extracted and analyzed by (f) ELISA and (g) immunocytochemistry using an antibody against CPDs. DAPI was used to stain the nuclei (Scale bar $=10 \mu \mathrm{m}$ ). ${ }^{*} p<0.05 \mathrm{vs}$. control, and \# $p<0.05$ vs. UVB-irradiated cells. 


\subsection{Effect of Horse Oil on UVB-Induced Apoptosis and MAPK Signaling}

As shown in the fluorescence micrographs in Figure 3a, control cells showed bright red fluorescence, indicating mitochondrial membrane polarization. However, UVB exposure reduced the intensity of red fluorescence and increased the intensity of green fluorescence, revealing mitochondrial membrane depolarization. In horse oil- and NAC-pretreated cells, the reduction in red fluorescence was inhibited (Figure 3a). Furthermore, while the amount of cytoplasmic histone-associated DNA fragments was 1.44-fold higher in UVB-irradiated than in control cells, the level of DNA fragmentation was significantly suppressed by 0.99-, 0.99-, and 1.19-fold in horse oil- and NAC-treated cells (Figure 3b). Next, to investigate the cytoprotective properties of horse oil against UVB-induced apoptosis, the cell nuclei were stained with Hoechst 33342 and observed by fluorescence microscopy. We previously demonstrated the UVB-induced apoptosis of keratinocytes in the presence of apoptotic bodies [23]. Numerous apoptotic bodies were detected in the UVB irradiation group, whereas apoptotic bodies in horse oil- or NAC-pretreated cells were significantly reduced (Figure 3c). Next, we investigated whether horse oil impacted the viability of UVB-irradiated keratinocytes. An MTT assay showed that the cell viabilities of horse oil- and NAC-pretreated cells were restored from $59.1 \%$ to $69.5 \%, 67.9 \%$, and $69.2 \%$, after UVB irradiation (Figure 3d). Caspase-9 is cleaved upon mitochondrial membrane disruption [24]. This active (cleaved) form of the enzyme and of its target, caspase-3, were evaluated by Western blotting. Horse oil suppressed the UVB-induced cleavage of caspase-9 (39 and $37 \mathrm{kDa}$ ) and cleaved caspase-3 (19 and $17 \mathrm{kDa})$, as further demonstrated by activation of PARP (89 kDa) (Figure 3e). In keratinocytes, phosphorylation of JNK1/2 and p38 MAPK is activated UVB-induced apoptosis [25], whereas extracellular signal-regulated kinases 1 and 2 (ERK1/2) are related to the cell survival pathway and their inhibition promotes UVB-induced apoptosis [26]. As shown in Figure 3f, horse oil significantly inhibited the phosphorylation of p38 and JNK after UVB irradiation. However, the UVB-dependent decrease in phospho-ERK was reversed by horse oil. These results indicate that horse oil protects against cell apoptosis controlled by MAPK signaling by inhibiting the mitochondrial caspase-dependent pathway.

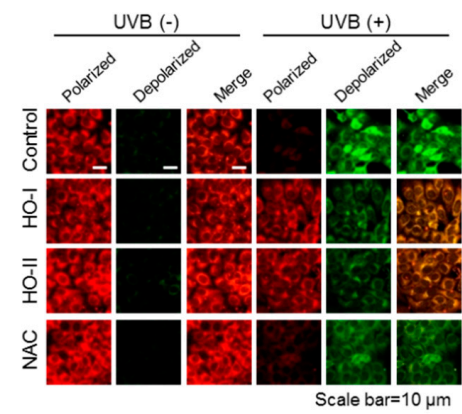

(a)

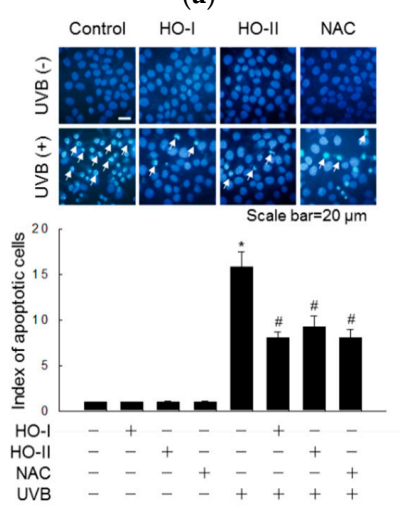

(c)

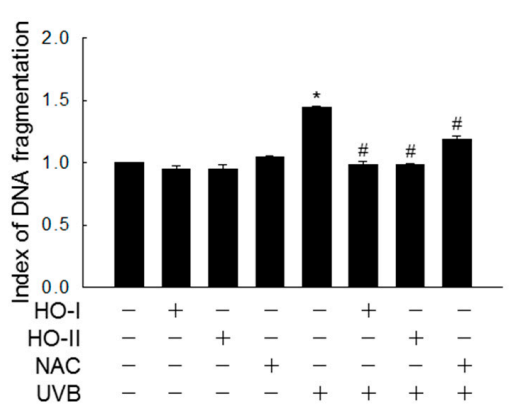

(b)

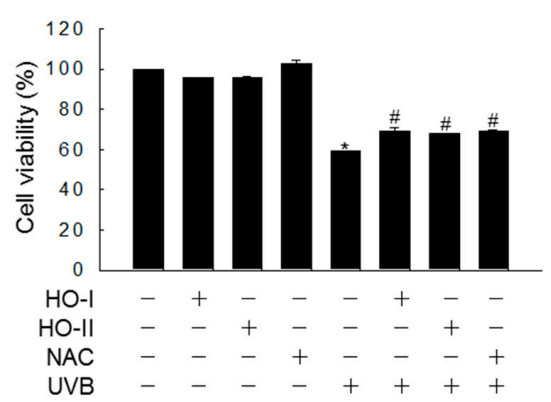

(d)

Figure 3. Cont. 


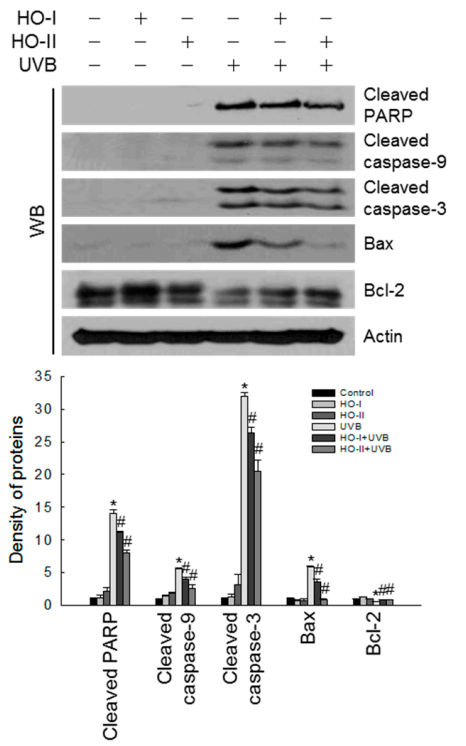

(e)

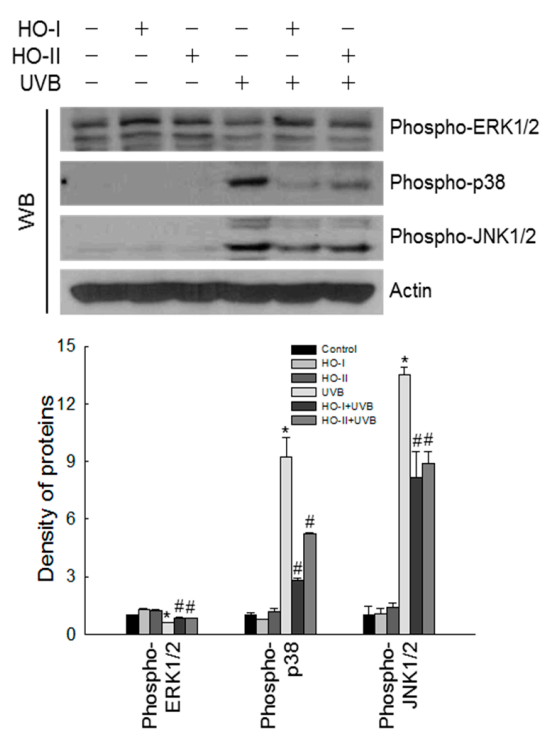

$(\mathbf{f})$

Figure 3. Horse oil attenuates UVB-induced apoptosis. HaCaT keratinocytes were treated with horse oil or NAC and exposed to UVB radiation $1 \mathrm{~h}$ later. Cells were then incubated for $24 \mathrm{~h}$. $\Delta \psi \mathrm{m}$ was analyzed by (a) confocal microscopy after staining the cells with JC-1 (Scale bar $=10 \mu \mathrm{m}$ ). (b) DNA fragmentation was quantified by ELISA. (c) Apoptotic bodies (arrows) were observed in cells stained with Hoechst 33342 dye and quantified by fluorescence microscopy (Scale bar $=10 \mu \mathrm{m}$ ). (d) Cell viability following UVB radiation was determined by MTT assay. (e,f) Western blotting with antibodies specific for (e) PARP, caspase-9, caspase-3, Bax, Bcl-2, actin, (f) phospho-ERK1/2, phospho-p38, and phospho-JNK1/2, and actin, and the results were quantified $(n=3) .{ }^{*} p<0.05$ vs. control, and \# $p<0.05$ vs. UVB-irradiated cells.

\subsection{Effect of Horse Oil on UVB Absorption}

Horse oil showed a high absorption ability in the UV range (200-400 nm), reaching a peak at $271 \mathrm{~nm}$, with absorption values of 0.28 and 0.51 for HO-I and HO-II, respectively (Figure 4). The absorbance of this value indicates that the horse oil has UVB light absorption properties, but does not completely prevent UVB ray from reaching the cells.

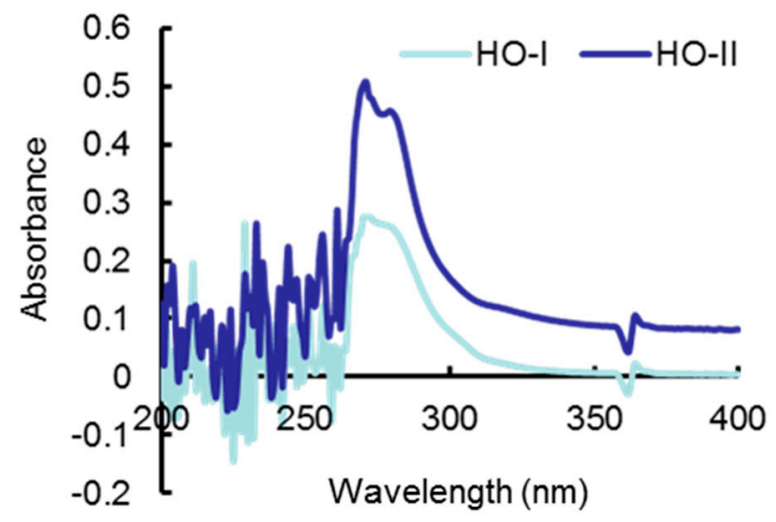

Figure 4. Horse oil absorbs UVB rays. The UVB absorption spectrum of horse oil was determined by UV scanning at $200-400 \mathrm{~nm}$. The maximum absorbance of horse oil appeared at $271 \mathrm{~nm}$, and the absorbance values of HO-I or HO-II were 0.2756 and 0.5067 , respectively.

\subsection{Effect of Horse Oil on UVB-Induced MMP Expression and Activation}

It has been reported that the activities of MMP-1, MMP-2, MMP-3, and MMP-9 are evidently increased in UV-induced photo-aging skin [27,28]. Horse oil inhibited the induction of MMP-1, MMP-2, 
and MMP-9 protein expression by UVB irradiation (Figure 5a). Furthermore, horse oil significantly inhibited the activity of MMP-1 induced by UVB radiation from $3.75 \mathrm{ng} / \mathrm{mL}$ to $3.06 \mathrm{ng} / \mathrm{mL}$ and $3.06 \mathrm{ng} / \mathrm{mL}$, respectively (Figure $5 \mathrm{~b}$ ). These results suggested that horse oil markedly suppressed the activation of MMP enzymes. AP-1, a heterodimeric protein consisting of proteins belonging to the Fos and Jun families, is a transcription factor capable of binding to $5^{\prime}$-TGAGTCA-3' DNA elements [29]. The AP-1 site plays an important role in the transcriptional activation of MMP promoters [30]. A chromatin immunoprecipitation (ChIP) assay revealed that horse oil attenuated UVB-induced binding of AP-1 to the MMP-1 promoter (Figure 5c).

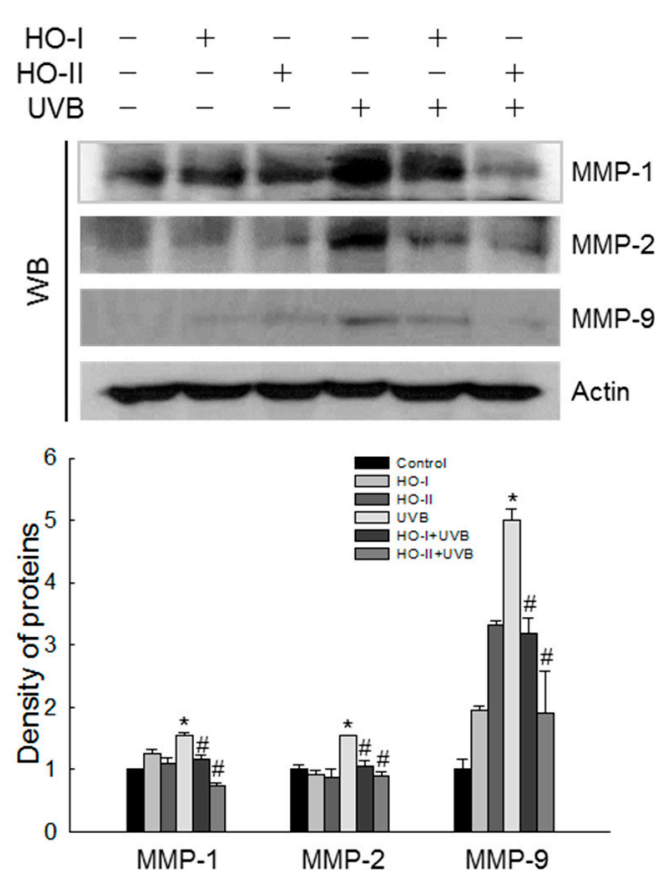

(a)

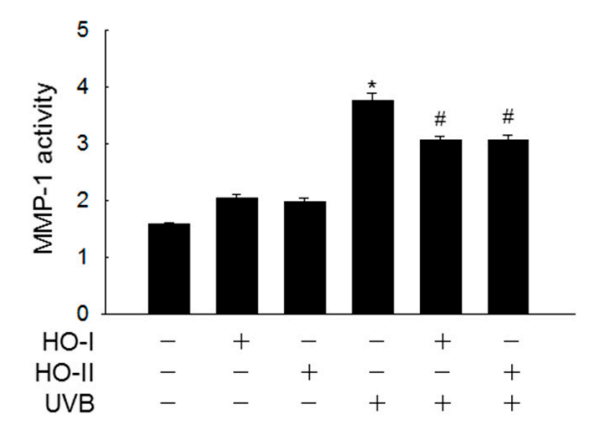

(b)

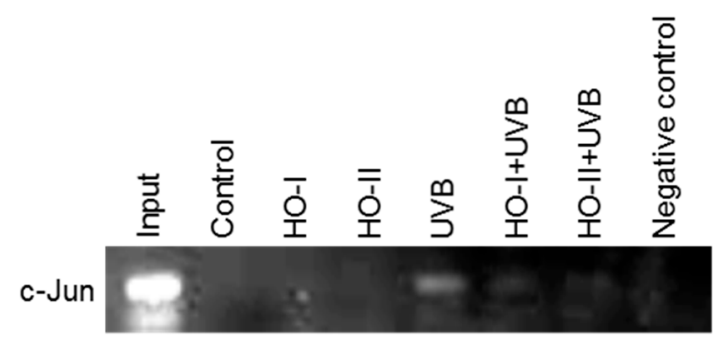

(c)

Figure 5. Horse oil reduces UVB-induced MMP expression and activation. (a) Western blot analysis of MMP-1, MMP-2, and MMP-9 protein expression and quantitative data are shown $(n=3)$. (b) Active MMP-1 was quantified in the culture supernatants. Cells were incubated in serum-free medium to eliminate interference from MMP- 1 in the serum. ${ }^{*} p<0.05 \mathrm{vs}$. control, and $\# p<0.05 \mathrm{vs}$. UVB-irradiated cells. (c) AP-1 binding to the MMP-1 promoter was assessed by ChIP assay.

\section{Discussion}

To provide a scientific basis for the skin-protective effect of horse oil, we focused on the protective mechanism of horse oil on UVB-induced oxidative stress in human HaCaT keratinocytes. The skin utilizes an effective antioxidant defense system that responds to UV-induced oxidative stress, including that caused by UVB exposure. However, excessive and prolonged exposure to UV radiation may overwhelm the skin's antioxidant system, leading to oxidative damage resulting in skin disorders such as sunburn, photosensitivity, and precancerous growth. As described above, UVB radiation can reach the epidermal basal cell layer of the skin; thus, its effect is most pronounced in epidermal cells, including keratinocytes.

Fatty acid analysis of the horse oils indicated that, although the two horse oils differ in fatty acid contents, they contain the same type of fatty acids. They are rich in natural nutrients, such as oleic acid, linoleic acid, palmitic acid, and other highly unsaturated fatty acids. The different contents may be mainly related to the different product formulations (Table 1). Extraction methods differ depending on the manufacturer's equipment, skill level, and other factors. Smear-type horse oil and dissolved horse oil have different effects, such as their degree of skin absorption. In the current study, we tested 
two types of horse oil at different dosages to study the protective effect of horse oils on UVB-induced cell damage.

The UV absorption characteristics of horse oil in Figure 4 indicate that horse oil has the ability to block UVB light from reaching the cell. However, its absorption capacity is not very strong at $0.312 \%$ concentration of horse oil, so the UV absorption properties of horse oil are not a major protective effect. We suggest that its protective effect is mainly caused by the antioxidant action of horse oil and the resulting changes in cell signaling processes. We demonstrated that horse oil scavenges DPPH free radicals in cell-free systems and scavenges $\mathrm{H}_{2} \mathrm{O}_{2}$ and UVB-induced intracellular ROS (Figure 1).

If excessive ROS are not rapidly removed, they may attack biological macromolecules, such as lipids, proteins, and DNA, resulting in extensive cellular oxidative damage that can disrupt cell function and contribute to cell death. However, some substances show cytoprotective effects against oxidative stress-induced cell damage induced by UVB exposure. The current study showed that horse oil significantly prevents UVB-induced peroxidation damage to lipid membranes and reduces the level of UVB-enhanced protein carbonylation. Additionally, horse oil significantly reduced oxidative DNA damage caused by UVB rays. Finally, horse oil showed significant protective effects against the major UVB-induced photoproduct, CPDs.

Notably, after exposure to UVB, apoptotic body formation and cell death signaling were stimulated in $\mathrm{HaCaT}$ keratinocytes. Horse oil pretreatment effectively inhibited apoptosis after UVB irradiation, likely by downregulating PARP, caspase-3, caspase-9, and Bax and upregulating Bcl-2. Further, MAPK signaling plays an important role in controlling cell proliferation, cell motility, MMP gene expression, and cell survival and death. The three major MAPK subfamilies in mammalian cells are JNK, ERK, and p38 [31]. Oxidative stress caused by ROS accumulation can initiate MAPK signaling through the phosphorylation of MAPK members [32]. This study revealed that UVB-induced JNK and p38 activation was reduced in horse oil-pretreated cells, while UVB-suppressed ERK activity was restored.

MMP-1 is a member of the collagenase subfamily of MMPs. Previous studies showed that UVB-induced ROS cause skin aging by activating MMP-1 [17]. Upon activation, MMP-1 initiates collagen breakdown by cleaving type I and type III collagens, which are then cleaved by MMP-2 and MMP-9 [33]. The gelatinolytic activities of MMP-2 and MMP-9 are central players in UV-irradiated skin damage and the formation of wrinkles [34]. A previous study suggested that antioxidants suppress UVB-induced MMP-9 activity in human HaCaT keratinocytes [35]. The MMP-1 promoter contains a binding site for AP-1, and UVB-induced AP-1 activation amplifies MMP-1 expression [36]. Accordingly, the present data show that horse oil can inhibit UVB-induced MMPs, such as MMP-1, MMP-2, and MMP-9, and suppresses UVB-induced AP-1 transcriptional activity in the MMP-1 promoter region.

In our system, oleic acid, which is the most abundant component of horse oil, showed a DPPH free radical-scavenging capacity of less than $10 \%$ in a cell-free system and showed no ability to scavenge intracellular ROS induced by $\mathrm{H}_{2} \mathrm{O}_{2}$ and UVB. Oleic acid also did not show absorption capacity at the UVB wavelength (data not shown). The second most unsaturated fatty acid in horse oil, linoleic acid, inhibits peroxidation, DNA damage, and apoptosis [37,38]. Our future studies will focus on identifying the fatty acids responsible for the protective effects of horse oil against oxidative stress-induced cell damage. The effects of single active ingredients of horse oil on cells have been reported previously. However, horse oil is a mixture of unsaturated and saturated fatty acids, and studies on their effects on cells are rare. The protective effect of horse oil on UV-induced skin may be mediated by various active ingredients. Further studies are needed to determine the molecular and pharmacodynamic mechanisms of horse oil in vitro and in vivo.

\section{Materials and Methods}

\subsection{Preparation of Horse Oil}

Horse oils were provided by Beihai Company (Jeju, Korea) and Daebong LS Company (Jeju). Horse oil (HO-I) provided by Beihai Company is a liquid product made from $100 \%$ pure horse oil 
extracted by vacuum distillation of horse fat. Horse oil (HO-II) provided by Daebong LS Company is a cream product made from $100 \%$ pure horse oil extracted from the water vapor of horse fat. The horse oil stock solution was diluted with horse oil stock solution:distilled water:Tween-80 at a ratio of 1:1:0.02, and the milky horse oil was obtained by ultrasonic treatment and then treated to the cells.

\subsection{Fatty Acid Analysis of Horse Oil}

The fatty acid content of horse oil was analyzed according to the AOAC official method 963.22 of Korea Food Research Institute (Jeollabuk-do, Korea).

\subsection{Cell Culture and UVB Radiation}

Human HaCaT keratinocytes were provided by CLS Cell Lines Service GmbH (Eppelheim, Germany). Cells were cultured in Dulbecco's modified Eagle's medium containing 10\% heat-inactivated fetal bovine serum (Life Technologies, Carlsbad, CA, USA) and antibiotic-antimycotic (Life Technologies) at $37^{\circ} \mathrm{C}$ in $5 \% \mathrm{CO}_{2}$. The cells were irradiated with UVB at a dose of $30 \mathrm{~mJ} / \mathrm{cm}^{2}$. After the cells were irradiated with UVB light, the original medium was replaced with new medium, and the experiment was carried out after incubation. The UVB source was a CL-1000M UV Crosslinker (UVP, Upland, CA, USA), which was used to deliver an energy spectrum corresponding to UVB wavelengths of $280-320 \mathrm{~nm}$.

\subsection{Cell Viability Assay}

Cells were seeded into 24-well plates at $0.315 \times 10^{5}$ cells per $\mathrm{cm}^{2}\left(0.6 \times 10^{5}\right.$ cells/well). After $16 \mathrm{~h}$ of incubation, the cells were treated with $0.039 \%, 0.078 \%, 0.156 \%, 0.312 \%, 0.625 \%, 1.25 \%$, or $2.5 \%$ horse oil (final concentrations) or pretreated with horse oil $(0.312 \%)$ and the positive control $N$-acetylcysteine ( $1 \mathrm{mM}$, NAC, Sigma-Aldrich, St. Louis, MO, USA). One hour later, the cells were UVB-irradiated. After one day of incubation at $37^{\circ} \mathrm{C}, 50 \mu \mathrm{L}$ of thiazolyl blue tetrazolium bromide (MTT, Amresco LLC, Solon, OH, USA) stock solution $(2 \mathrm{mg} / \mathrm{mL}$ ) was added to each well. After $4 \mathrm{~h}$, the formazan crystals in each well were dissolved in $350 \mu \mathrm{L}$ of dimethyl sulfoxide (Amresco LLC) and the absorbance at $540 \mathrm{~nm}$ was read on a VersaMax ELISA Microplate Reader (Molecular Devices, Sunnyvale, CA, USA) [39].

\subsection{Detection of 2,2-Diphenyl-1-picrylhydrazyl (DPPH) Radicals}

Horse oil $(0.156 \%, 0.312 \%, 0.625 \%, 1.25 \%$, and $2.5 \%$, final concentrations) and positive control NAC (2 mM) were added to 96-well plates containing $0.15 \mathrm{mM}$ DPPH (Sigma-Aldrich) in ethanol. The reaction mixture was shaken vigorously; after $3 \mathrm{~h}$, the amount of DPPH remaining was detected at $520 \mathrm{~nm}$. The DPPH radical-scavenging activity (\%) was calculated as: [(optical density of DPPH radical treatment) - (optical density of horse oil or NAC with DPPH radical treatment)] $\times 100 /$ (optical density of DPPH radical treatment).

\subsection{Detection of Intracellular ROS}

Cells were seeded into 96-well plates at $0.47 \times 10^{5}$ cells per $\mathrm{cm}^{2}\left(0.15 \times 10^{5}\right.$ cells /well $)\left(\mathrm{H}_{2} \mathrm{O}_{2}\right)$ or $0.52 \times 10^{5}$ cells per $\mathrm{cm}^{2}\left(0.1 \times 10^{5}\right.$ cells/well $)(\mathrm{UVB})$. After $16 \mathrm{~h}, 0.039 \%, 0.078 \%, 0.156 \%, 0.312 \%$, $0.625 \%, 1.25 \%$, or $2.5 \%$ horse oil (final concentrations) and $1 \mathrm{mM} \mathrm{NAC}$ were added, and the plates were incubated at $37^{\circ} \mathrm{C}$ for $30 \mathrm{~min}$ or $1 \mathrm{~h}$. Next, the cells were exposed to $\mathrm{H}_{2} \mathrm{O}_{2}(500 \mu \mathrm{M})$ or UVB light, and then further incubated at $37^{\circ} \mathrm{C}$ for $30 \mathrm{~min}$ or $24 \mathrm{~h}$. A $2^{\prime}, 7^{\prime}$-dichlorodihydrofluorescein diacetate $\left(\mathrm{H}_{2}\right.$ DCFDA; Molecular Probes, Eugene, OR, USA) solution $(25 \mu \mathrm{M})$ was added, and the cells were incubated for $10 \mathrm{~min}$. DCF fluorescence was measured with a PerkinElmer LS-5B spectrofluorometer (Waltham, MA, USA). For image analysis, cells were seeded onto a 4-well glass slide at $0.35 \times 10^{5}$ cells per $\mathrm{cm}^{2}\left(0.6 \times 10^{5}\right.$ cells $/$ well $)$ and cultured for $16 \mathrm{~h}$. The cells were treated with horse oil $(0.312 \%)$ and NAC $(1 \mathrm{mM})$ for $1 \mathrm{~h}$, exposed to UVB, and incubated for another $24 \mathrm{~h}$ at $37^{\circ} \mathrm{C} . \mathrm{H}_{2}$ DCFDA $(100 \mu \mathrm{M})$ was added to each well, and the stained cells were assessed under a FV1200 laser scanning microscope 
(Carl Zeiss, Jena, Germany). For flow cytometry analysis, cells were seeded into a 6-well plate at $0.21 \times 10^{5}$ cells per $\mathrm{cm}^{2}\left(2.0 \times 10^{5}\right.$ cells/well). The cells were treated with horse oil and NAC under the above conditions. After incubation with $\mathrm{H}_{2}$ DCFDA at $37^{\circ} \mathrm{C}$ for $30 \mathrm{~min}$, the cells were analyzed with a BD FACSCalibur flow cytometer (BD Biosciences, San Jose, CA, USA).

\subsection{Lipid Peroxidation Assay}

The level of 8-isoprostane, a marker of lipid peroxidation, was measured using a commercial enzyme immunoassay (Cayman Chemical, Ann Arbor, MI, USA) according to the manufacturer's protocol [40]. Additionally, lipid peroxidation was assessed by using fluorescent probe diphenyl-1-pyrenylphosphine (DPPP; Molecular Probes). Cells were incubated with $5 \mu \mathrm{M}$ DPPP for 15 min in the dark, washed with PBS, and mounted on a microscope slide in mounting medium (DAKO, Carpinteria, CA, USA). DPPP fluorescence was analyzed under FV1200 laser-scanning microscope at an excitation wavelength of $351 \mathrm{~nm}$ and emission wavelength of $380 \mathrm{~nm}$.

\subsection{Protein Carbonyl Formation}

The formation of protein carbonyl, a marker of protein oxidation, was assessed by using an Oxiselect ${ }^{\mathrm{TM}}$ protein carbonyl ELISA kit (Cell Biolabs, San Diego, CA, USA) according to the manufacturer's protocol.

\subsection{Single-Cell Gel Electrophoresis (Comet Assay)}

DNA oxidation was assessed in an alkaline comet assay. A cell suspension was mixed with $0.7 \%$ low-melting agarose at $39{ }^{\circ} \mathrm{C}$ and spread onto a fully frosted microscope slide pre-coated with $1 \%$ normal melted agarose. After curation, the slides were covered with $0.7 \%$ low melting agarose and immersed in lysis buffer $(2.5 \mathrm{M} \mathrm{NaCl}, 100 \mathrm{mM} \mathrm{Na} 2$ EDTA, $10 \mathrm{mM}$ Tris-pH10, $1 \% \mathrm{~N}$-lauroylsarcosinate, and $1 \%$ Triton $\mathrm{X}-100$ ) at $4{ }^{\circ} \mathrm{C}$ for $1.5 \mathrm{~h}$. Electrophoresis was carried out for $20 \mathrm{~min}$ at $300 \mathrm{~mA}, 25 \mathrm{~V}$, and the gel was stained with ethidium bromide. The percentage of DNA in the comet tail for each cell was recorded as described previously [23].

\subsection{Detection of 8-Oxoguanine (8-oxoG)}

8-OxoG, a marker of oxidative DNA damage, was evaluated in a fluorescent binding assay [41]. Cells were seeded onto a 4-well chamber slide at $0.35 \times 10^{5}$ cells per cm $\mathrm{cm}^{2}\left(0.6 \times 10^{5}\right.$ cells $/$ well $)$. After $16 \mathrm{~h}$ of incubation, the cells were treated with horse oil $(0.312 \%)$ and NAC $(1 \mathrm{mM})$ for $1 \mathrm{~h}$ and then exposed to UVB and incubated at $37^{\circ} \mathrm{C}$ for $24 \mathrm{~h}$. The cells were fixed and permeabilized with ice-cold methanol for $15 \mathrm{~min}$, and the 8-oxoG level was determined by measuring fluorescence under an FV1200 laser-scanning microscope after a reaction with avidin-TRITC conjugate (Sigma-Aldrich).

\subsection{CPD Detection}

The amount of CPD was determined by ELISA and immunofluorescence microscopy, as described previously [42]. For ELISA, genomic DNA was reacted with anti-CPD antibody (Cosmo Bio, Tokyo, Japan). For immunofluorescence microscopy, cells were seeded onto 4-well chamber slides at $0.35 \times 10^{5}$ cells per $\mathrm{cm}^{2}\left(0.6 \times 10^{5}\right.$ cells / well). The cells were treated with horse oil $(0.312 \%)$, and after $1 \mathrm{~h}$ exposure to UVB, the cells were incubated at $37^{\circ} \mathrm{C}$ for an additional $1 \mathrm{~h}$. After fixation, permeabilization, and denaturation of the DNA, the cells were blocked with FBS, exposed to anti-CPD antibody and Alexa Fluor 594-conjugated $\mathrm{F}\left(\mathrm{ab}^{\prime}\right) 2$ fragment of anti-mouse IgG, and transferred to microscope slides in DAPI containing mounting medium (Vector Laboratories, Burlingame, CA, USA). Images were collected on a Zeiss confocal microscope using the LSM 510 program. 


\subsection{Mitochondrial Membrane Potential $(\Delta \psi m)$ Analysis}

Cells were treated with mitochondrial membrane permeant dye JC-1 $(10 \mu \mathrm{g} / \mathrm{mL})$ for $15 \mathrm{~min}$ at $37^{\circ} \mathrm{C}$. Next, the cells were washed with PBS, mounted on a microscope slide, and analyzed under an FV1200 laser-scanning microscope [43].

\subsection{DNA Fragmentation Detection}

Cellular DNA fragmentation was assessed by detecting the degree of cytoplasmic histone-associated DNA fragmentation with a diagnostics kit (Roche, Basel, Switzerland) according to the manufacturer's protocol.

\subsection{Nuclear Staining with Hoechst 33342}

The DNA-specific fluorescent dye Hoechst $33342(1.5 \mu \mathrm{L}, 10 \mathrm{mg} / \mathrm{mL}$ stock) was added to each well, and cells were incubated at $37^{\circ} \mathrm{C}$ for $10 \mathrm{~min}$. Stained cells were observed under a fluorescence microscope equipped with a CoolSNAP-Pro color digital camera (Media Cybernetics, Rockville, MD, USA). The extents of nuclear condensation and apoptotic body formation were evaluated. The apoptotic index was calculated as follows: (number of apoptotic cells in treated group/total number of cells in treated group)/(number of apoptotic cells in control group/total number of cells in control group).

\subsection{Western Blot Analysis}

Thirty micrograms of protein were electrophoresed on $12 \%$ sodium dodecyl sulfate-polyacrylamide gels and transferred onto nitrocellulose membranes. The membranes were incubated with primary antibodies, followed by horseradish peroxidase-conjugated secondary antibody conjugates. Protein bands were visualized by using a Western blotting detection kit. Primary antibodies against PARP, caspase-3, caspase-9, phospho-JNK1/2, phospho-p38, and phospho-ERK1/2 were purchased from Cell Signaling Technology (Danvers, MA, USA); primary antibodies against Bax, Bcl-2, MMP-1, and actin were purchased from Santa Cruz Biotechnology (Dallas, TX, USA); and primary antibodies against MMP-2 and MMP-9 were obtained from Abcam (Cambridge, UK).

\subsection{UV/visible Light Absorption Analysis}

The stock solutions of horse oil were diluted in dimethyl sulfoxide at a ratio of 1:1000 $(v / v)$. The solutions were scanned with UV light (range 200-400 nm) using a Biochrom Libra S22 UV/Visible spectrophotometer (Biochrom, Cambridge, UK).

\subsection{MMP-1 Activity Assay}

MMP-1 activity was measured by using a Fluorokine ${ }^{\circledR}$ E human active MMP-1 assay kit (R\&D Systems, Minneapolis, MN, USA) according to the manufacturer's protocol.

\subsection{Chromatin Immunoprecipitation (ChIP) Assay}

ChIP assays were performed using the SimpleChIPTM enzymatic chromatin IP kit (Cell Signaling Technology) as previously described [44]. Immuno-precipitated DNA fragments were purified on spin columns and the recovered DNA was subjected to 35 cycles of PCR. Specific primers targeting the MMP-1 gene promoter $(-67$ to +94 from the transcription start site of the MMP-1 gene, Bionics) were as follows: sense $5^{\prime}$-CCTCTTGCTGCTCCAATATC- $3^{\prime}$ and antisense $5^{\prime}$-TCTGCTAGGAGTCACCATTTC-3'. The PCR products were separated on an agarose gel, DNA bands were stained with $\mathrm{EtBr}$, and the results were analyzed with ImageJ software (NIH, Bethesda, MD, USA). 


\subsection{Data Analysis}

Data are expressed as the mean \pm standard error (SE). Means were compared by analysis of variance followed by Tukey's post-hoc test. A $p$-value $<0.05$ was considered significant.

\section{Conclusions}

Our results show that the UVB protective effects of HO-I and HO-II were slightly but not significantly different. In summary, horse oil prevents UVB-stimulated oxidative stress by absorbing UVB radiation and removing ROS, reducing cell damage, and preventing cell death and aging. Therefore, the present data support that horse oil is a promising skin protectant for preventing and treating skin diseases associated with oxidative stress.

Author Contributions: M.J.P. and J.W.H. conceived and designed the experiments and wrote the paper; M.J.P. and A.X.Z. performed the experiments; M.J.P., K.A.K., and J.W.H. analyzed the data; and H.K.K., Y.S.K., and B.S.K. contributed reagents/materials/analysis tools.

Funding: This work was supported by grant from the Basic Research Laboratory Program (NRF-2017R1A4A1014512) by the National Research Foundation of Korea (NRF) grant funded by the Ministry of Science, ICT and future Planning (MSIP) of Korea government.

Conflicts of Interest: The authors declare no conflict of interest.

\section{Abbreviations}

$\begin{array}{ll}\text { AP-1 } & \text { Activation protein 1 } \\ \text { CPD } & \text { Cyclobutane pyrimidine dimer } \\ \text { DPPH } & \text { 2,2-Diphenyl-1-picrylhydrazyl } \\ \text { DPPP } & \text { Diphenyl-1-pyrenylphosphine } \\ \text { ERK1/2 } & \text { Extracellular signal-regulated kinase 1/2 } \\ \mathrm{H}_{2} \text { DCFDA } & 2^{\prime}, 7^{\prime} \text {-dichlorodihydrofluorescein diacetate } \\ \mathrm{H}_{2} \mathrm{O}_{2} & \text { Hydrogen peroxide } \\ \text { JNK1/2 } & \text { c-Jun N-terminal kinase 1/2 } \\ \text { MMP } & \text { Matrix metalloproteinase } \\ \text { MTT } & \text { Thiazolyl blue tetrazolium bromide } \\ \text { NAC } & \text { N-acetylcysteine } \\ \text { ROS } & \text { Reactive oxygen species } \\ \text { UV } & \text { Ultraviolet }\end{array}$

\section{References}

1. Brooker, E.G.; Shorland, F.B. Studies on the composition of horse oil. 1. Composition of horse oil in relation to the depot fats of other pasture-fed animals. Biochem. J. 1950, 46, 80-85. [CrossRef]

2. Al-Shudiefat, A.A.; Sharma, A.K.; Bagchi, A.K.; Dhingra, S.; Singal, P.K. Oleic acid mitigates TNF- $\alpha$-induced oxidative stress in rat cardiomyocytes. Mol. Cell. Biochem. 2013, 372, 75-82. [CrossRef]

3. Guzmán, D.C.; Brizuela, N.O.; Herrera, M.O.; Olguín, H.J.; García, E.H.; Peraza, A.V.; Mejía, G.B. Oleic acid protects against oxidative stress exacerbated by cytarabine and doxorubicin in rat brain. Anticancer Agents Med. Chem. 2016, 16, 1491-1495. [CrossRef]

4. Basiricò, L.; Morera, P.; Dipasquale, D.; Tröscher, A.; Bernabucci, U. Comparison between conjugated linoleic acid and essential fatty acids in preventing oxidative stress in bovine mammary epithelial cells. J. Dairy Sci. 2017, 100, 2299-2309. [CrossRef]

5. Kim, H.; Youn, K.; Yun, E.Y.; Hwang, J.S.; Jeong, W.S.; Ho, C.T.; Jun, M. Oleic acid ameliorates A $\beta$-induced inflammation by downregulation of COX-2 and iNOS via NFKB signaling pathway. J. Funct. Foods 2015, 14, 1-11. [CrossRef]

6. Kim, H.H.; Shin, C.M.; Park, C.H.; Kim, K.H.; Cho, K.H.; Eun, H.C.; Chung, J.H. Eicosapentaenoic acid inhibits UV-induced MMP-1 expression in human dermal fibroblasts. J. Lipid Res. 2005, 46, 1712-1720. [CrossRef] [PubMed] 
7. Kleszczyński, K.; Zillikens, D.; Fischer, T.W. Melatonin enhances mitochondrial ATP synthesis, reduces reactive oxygen species formation, and mediates translocation of the nuclear erythroid 2-related factor 2 resulting in activation of phase- 2 antioxidant enzymes ( $\gamma$-GCS, HO-1, NQO1) in ultraviolet radiation-treated normal human epidermal keratinocytes (NHEK). J. Pineal Res. 2016, 61, 187-197. [PubMed]

8. Kleszczyński, K.; Bilska, B.; Stegemann, A.; Flis, D.J.; Ziolkowski, W.; Pyza, E.; Luger, T.A.; Reiter, R.J.; Böhm, M.; Slominski, A.T. Melatonin and its metabolites ameliorate UVR-induced mitochondrial oxidative stress in human MNT-1 melanoma cells. Int. J. Mol. Sci. 2018, 19, 3786. [CrossRef]

9. Sklar, L.R.; Almutawa, F.; Lim, H.W.; Hamzavi, I. Effects of ultraviolet radiation, visible light, and infrared radiation on erythema and pigmentation: A review. Photochem. Photobiol. Sci. 2013, 12, 54-64. [CrossRef]

10. Moore, C.; Cevikbas, F.; Pasolli, H.A.; Chen, Y.; Kong, W.; Kempkes, C.; Parekh, P.; Lee, S.H.; Kontchou, N.A.; Yeh, I.; et al. UVB radiation generates sunburn pain and affects skin by activating epidermal TRPV4 ion channels and triggering endothelin-1 signaling. Proc. Natl. Acad. Sci. USA 2013, 110, E3225-E3234. [CrossRef]

11. Kleszczyński, K.; Zwicker, S.; Tukaj, S.; Kasperkiewicz, M.; Zillikens, D.; Wolf, R.; Fischer, T.W. Melatonin compensates silencing of heat shock protein 70 and suppresses ultraviolet radiation-induced inflammation in human skin ex vivo and cultured keratinocytes. J. Pineal Res. 2015, 58, 117-126. [CrossRef]

12. Panich, U.; Sittithumcharee, G.; Rathviboon, N.; Jirawatnotai, S. Ultraviolet radiation-induced skin aging: The role of DNA damage and oxidative stress in epidermal stem cell damage mediated skin aging. Stem Cells Int. 2016, 2016, 7370642. [CrossRef]

13. Balupillai, A.; Nagarajan, R.P.; Ramasamy, K.; Govindasamy, K.; Muthusamy, G. Caffeic acid prevents UVB radiation induced photocarcinogenesis through regulation of PTEN signaling in human dermal fibroblasts and mouse skin. Toxicol. Appl. Pharmacol. 2018, 352, 87-96. [CrossRef]

14. Tong, L.; Wu, S. The Mechanisms of carnosol in chemoprevention of ultraviolet B-light-induced non-melanoma skin cancer formation. Sci. Rep. 2018, 8, 3574. [CrossRef] [PubMed]

15. Janjetovic, Z.; Jarrett, S.G.; Lee, E.F.; Duprey, C.; Reiter, R.J.; Slominski, A.T. Melatonin and its metabolites protect human melanocytes against UVB-induced damage: Involvement of NRF2-mediated pathways. Sci. Rep. 2017, 7, 1274. [CrossRef] [PubMed]

16. Kim, S.I.; Jin, S.G.; Pfeifer, G.P. Formation of cyclobutane pyrimidine dimers at dipyrimidines containing 5-hydroxymethylcytosine. Photochem. Photobiol. Sci. 2013, 12, 1409-1415. [CrossRef] [PubMed]

17. Hwang, E.; Lee, D.G.; Park, S.H.; Oh, M.S.; Kim, S.Y. Coriander leaf extract exerts antioxidant activity and protects against UVB-induced photoaging of skin by regulation of procollagen type I and MMP-1 expression. J. Med. Food 2014, 17, 985-995. [CrossRef] [PubMed]

18. Pittayapruek, P.; Meephansan, J.; Prapapan, O.; Komine, M.; Ohtsuki, M. Role of matrix metalloproteinases in photoaging and photocarcinogenesis. Int. J. Mol. Sci. 2016, 17, 868. [CrossRef]

19. Cho, B.O.; Che, D.N.; Shin, J.Y.; Kang, H.J.; Kim, J.H.; Kim, H.Y.; Cho, W.G.; Jang, S.I. Ameliorative effects of Diospyros lotus leaf extract against UVB-induced skin damage in BALB/c mice. Biomed. Pharmacother. 2017, 95, 264-274. [CrossRef]

20. Misawa, E.; Tanaka, M.; Saito, M.; Nabeshima, K.; Yao, R.; Yamauchi, K.; Abe, F.; Yamamoto, Y.; Furukawa, F. Protective effects of Aloe sterols against UVB-induced photoaging in hairless mice. Photodermatol. Photoimmunol. Photomed. 2017, 33, 101-111. [CrossRef] [PubMed]

21. Sun, Z.; Park, S.Y.; Hwang, E.; Zhang, M.; Seo, S.A.; Lin, P.; Yi, T.H. Thymus vulgaris alleviates UVB irradiation induced skin damage via inhibition of MAPK/AP-1 and activation of Nrf2-ARE antioxidant system. J. Cell. Mol. Med. 2017, 21, 336-348. [CrossRef] [PubMed]

22. Han, A.R.; Nam, M.H.; Lee, K.W. Plantamajoside inhibits UVB and advanced glycation end products-induced MMP-1 expression by suppressing the MAPK and NF-кB pathways in HaCaT cells. Photochem. Photobiol. 2016, 92, 708-719. [CrossRef]

23. Oh, M.C.; Piao, M.J.; Fernando, P.M.; Han, X.; Hewage, S.R.K.M.; Park, J.E.; Ko, M.S.; Jung, U.; Kim, I.G.; Hyun, J.W. Baicalein protects human skin cells against ultraviolet B-induced oxidative stress. Biomol. Ther. 2016, 24, 616-622. [CrossRef] [PubMed]

24. Perkins, C.L.; Fang, G.; Kim, C.N.; Bhalla, K.N. The role of Apaf-1, caspase-9, and bid proteins in etoposideor paclitaxel-induced mitochondrial events during apoptosis. Cancer Res. 2000, 60, 1645-1653. 
25. Afnan, Q.; Kaiser, P.J.; Rafiq, R.A.; Nazir, L.A.; Bhushan, S.; Bhardwaj, S.C.; Sandhir, R.; Tasduq, S.A. Glycyrrhizic acid prevents ultraviolet-B-induced photodamage: a role for mitogen-activated protein kinases, nuclear factor kappa B and mitochondrial apoptotic pathway. Exp. Dermatol. 2016, 25, 440-446. [CrossRef]

26. Moriyama, M.; Moriyama, H.; Uda, J.; Kubo, H.; Nakajima, Y.; Goto, A.; Morita, T.; Hayakawa, T. BNIP3 upregulation via stimulation of ERK and JNK activity is required for the protection of keratinocytes from UVB-induced apoptosis. Cell Death Dis. 2017, 8, e2576. [CrossRef]

27. Chen, T.; Hou, H.; Fan, Y.; Wang, S.; Chen, Q.; Si, L.; Li, B. Protective effect of gelatin peptides from pacific cod skin against photoaging by inhibiting the expression of MMPs via MAPK signaling pathway. J. Photochem. Photobiol. B 2016, 165, 34-41. [CrossRef]

28. Park, H.C.; Jung, T.K.; Kim, M.J.; Yoon, K.S. Protective effect of Cornus walteri Wangerin leaf against UVB irradiation induced photoaging in human reconstituted skin. J. Ethnopharmacol. 2016, 193, 445-449. [CrossRef]

29. Hong, S.; Wang, D.; Horton, J.R.; Zhang, X.; Speck, S.H.; Blumenthal, R.M.; Cheng, X. Methyl-dependent and spatial-specific DNA recognition by the orthologous transcription factors human AP-1 and Epstein-Barr virus Zta. Nucleic Acids Res. 2017, 45, 2503-2515. [CrossRef] [PubMed]

30. Lu, J.; Guo, J.H.; Tu, X.L.; Zhang, C.; Zhao, M.; Zhang, Q.W.; Gao, F.H. Tiron inhibits UVB-induced AP-1 binding sites transcriptional activation on MMP-1 and MMP-3 promoters by MAPK signaling pathway in human dermal fibroblasts. PLoS ONE 2016, 11, e0159998. [CrossRef]

31. Kim, J.; Kim, M.B.; Yun, J.G.; Hwang, J.K. Protective effects of standardized Siegesbeckia glabrescens extract and its active compound kirenol against UVB-induced photoaging through inhibition of MAPK/NF- $\mathrm{KB}$ pathways. J. Microbiol. Biotechnol. 2017, 27, 242-250. [CrossRef]

32. Son, Y.; Kim, S.; Chung, H.T.; Pae, H.O. Reactive oxygen species in the activation of MAP kinases. Methods Enzymol. 2013, 528, 27-48. [PubMed]

33. Jung, Y.; Kim, J.C.; Choi, Y.; Lee, S.; Kang, K.S.; Kim, Y.K.; Kim, S.N. Eupatilin with PPAR $\alpha$ agonistic effects inhibits TNF $\alpha$-induced MMP signaling in HaCaT cells. Biochem. Biophys. Res. Commun. 2017, 493, 220-226. [CrossRef] [PubMed]

34. Amano, S. Characterization and mechanisms of photoageing-related changes in skin. Damages of basement membrane and dermal structures. Exp. Dermatol. 2016, 25, 14-19. [CrossRef] [PubMed]

35. Ji, D.; You, L.; Ren, Y.; Wen, L.; Zheng, G.; Li, C. Protective effect of polysaccharides from Sargassum fusiforme against UVB-induced oxidative stress in HaCaT human keratinocytes. J. Funct. Foods 2017, 36, 332-340. [CrossRef]

36. Goffin, L.; Seguin-Estévez, Q.; Alvarez, M.; Reith, W.; Chizzolini, C. Transcriptional regulation of matrix metalloproteinase- 1 and collagen 1A2 explains the anti-fibrotic effect exerted by proteasome inhibition in human dermal fibroblasts. Arthritis Res. Ther. 2010, 12, R73. [CrossRef]

37. Beeharry, N.; Lowe, J.E.; Hernandez, A.R.; Chambers, J.A.; Fucassi, F.; Cragg, P.J.; Green, M.H.; Green, I.C. Linoleic acid and antioxidants protect against DNA damage and apoptosis induced by palmitic acid. Mutat. Res. 2003, 530, 27-33. [CrossRef]

38. Chen, X.; Li, L.; Liu, X.; Luo, R.; Liao, G.; Li, L.; Liu, J.; Cheng, J.; Lu, Y.; Chen, Y. Oleic acid protects saturated fatty acid mediated lipotoxicity in hepatocytes and rat of non-alcoholic steatohepatitis. Life Sci. 2018, 203, 291-304. [CrossRef]

39. Park, M.A.; Sim, M.J.; Kim, Y.C. Anti-photoaging effects of Angelica acutiloba root ethanol extract in human dermal fibroblasts. Toxicol. Res. 2017, 33, 125-134. [CrossRef] [PubMed]

40. Chang, M.C.; Chan, C.P.; Chen, Y.J.; Hsien, H.C.; Chang, Y.C.; Yeung, S.Y.; Jeng, P.Y.; Cheng, R.H.; Hahn, L.J.; Jeng, J.H. Areca nut components stimulate ADAM17, IL-1 $\alpha$, PGE2 and 8-isoprostane production in oral keratinocyte: role of reactive oxygen species, EGF and JAK signaling. Oncotarget 2016, 7, 16879-16894. [PubMed]

41. Lee, H.S.; Lee, S.J.; Yu, H.J.; Lee, J.H.; Cho, H.Y. Fermentation with Lactobacillus enhances the preventive effect of garlic extract on high fat diet-induced hepatic steatosis in mice. J. Funct. Foods 2017, 30, 125-133. [CrossRef] 
42. Piao, M.J.; Ahn, M.J.; Kang, K.A.; Kim, K.C.; Cha, J.W.; Lee, N.H.; Hyun, J.W. Phloroglucinol enhances the repair of UVB radiation-induced DNA damage via promotion of the nucleotide excision repair system in vitro and in vivo. DNA Repair 2015, 28, 131-138. [CrossRef] [PubMed]

43. Park, J.E.; Piao, M.J.; Kang, K.A.; Shilnikova, K.; Hyun, Y.J.; Oh, S.K.; Jeong, Y.J.; Chae, S.; Hyun, J.W. A benzylideneacetophenone derivative induces apoptosis of radiation-resistant human breast cancer cells via oxidative stress. Biomol. Ther. 2017, 25, 404-410. [CrossRef] [PubMed]

44. Piao, M.J.; Kang, K.A.; Ryu, Y.S.; Shilnikova, K.; Park, J.E.; Hyun, Y.J.; Zhen, A.X.; Kang, H.K.; Koh, Y.S.; Ahn, M.J.; Hyun, J.W. The red algae compound 3-bromo-4,5-dihydroxybenzaldehyde protects human keratinocytes on oxidative stress-related molecules and pathways activated by UVB irradiation. Mar. Drugs 2017, 15, 268. [CrossRef] [PubMed] 